\title{
PEMANFAATAN LIMBAH KULIT PISANG KEPOK (Musa acuminata $\times$ balbisiana) SEBAGAI MEDIA FILTRASI PENINGKATAN KUALITAS AIR (TINGKAT KEJERNIHAN AIR, NILAI pH DAN TDS)
}

\author{
The Utilization of Kepok Banana Peel (Musa Acuminata $\times$ \\ Balbisiana) As Filtration Media To Increase Water Quality (Water \\ Clarity, pH Value, and TDS)
}

\author{
Putri Ade Rahma Yulis*, Yelfira Sari, Desti \\ Universitas Islam Riau, Pekanbaru \\ email: putriaderahmayulis@edu.uir.ac.id
}

\begin{abstract}
Abstrak. Berdasarkan hasil pendataan oleh Badan Pusat Statistik (BPS) bahwa pencemaran terbesar adalah pencemaran air, diikuti pencemaran udara dan tanah. Salah satu penyebab pencemaran air tersebut berasal dari limbah rumah tangga dan limbah industri. Atas dasar permasalahan tersebut penelitian ini bertujuan meningkatkan kualitas fisik air dengan memanfaatkan limbah kulit pisang. Untuk proses penelitian yang dilakukan adalah air limbah difiltrasi menggunakan serbuk simplisia kulit pisang kepok dengan variasi jumlah media filtrasi dan waktu filtrasi. Hasil yang diperoleh terjadi peningkatan tingkat kejernihan air limbah dari warna kecoklatan menjadi bening. Untuk nilai $\mathrm{pH}$ dan TDS pada variasi jumlah media filtrasi yaitu dari $\mathrm{pH}$ awal 4,9 dan TDS $477 \mathrm{mg} / \mathrm{L}$ menjadi $\mathrm{pH}$ 5,7 dan TDS $316 \mathrm{mg} / \mathrm{L}$ (filtrasi $30 \mathrm{~g}$ kulit pisang), $\mathrm{pH}$ 6,3 dan TDS $310 \mathrm{mg} / \mathrm{L}$ (filtrasi $50 \mathrm{~g}$ kulit pisang), pH 6,6 dan TDS $333 \mathrm{mg} / \mathrm{L}$ (filtrasi $70 \mathrm{~g}$ kulit pisang), $\mathrm{pH}$ 6,9 dan TDS $348 \mathrm{mg} / \mathrm{L}$ (filtrasi $90 \mathrm{~g}$ kulit pisang). Kemudian untuk variasi waktu filtrasi didapatkan hasil yaitu pH 5,3 dan TDS 409 mg/L (filtrasi 3 jam), pH 5,5 dan TDS $342 \mathrm{mg} / \mathrm{L}$ (filtrasi 5 jam), pH 6,3 dan TDS $314 \mathrm{mg} / \mathrm{L}$ (filtrasi 7 jam), pH 6,6 dan TDS $303 \mathrm{mg} / \mathrm{L}$ (filtrasi 9 jam ). Berdasarkan data perubahan $\mathrm{pH}$ dan TDS serta tingkat kejernihan air tersebut dapat disimpulkan bahwa kulit pisang kepok mempunyai efektivitas cukup tinggi dan berpotensi sebagai biosorben ramah lingkungan dan dapat dikembangkan lebih lanjut dengan proses aktivasi dan uji parameter lainnya untuk mengurangi dampak pencemaran lingkungan.
\end{abstract}

Kata kunci: Kulit Pisang, Filtrasi, Kualitas air

Abstract. Based on the results by the Central Statistics Agency (BPS), the biggest pollution is water pollution, then air and soil pollution. One of the causes of water pollution comes from household and industrial waste. Based on these problems, we studied to improve the physical quality of water by utilizing banana peel waste. For the research, the wastewater was filtered using kepok banana peel with variations in the amount of filtration media and filtration time. The results obtained were an increase in the level of clarity of the wastewater from brown to a clearer color. For the $\mathrm{pH}$ value and TDS in the variation of the amount of filtration media, there was an increase in the $\mathrm{pH}$ value, starting from $\mathrm{pH} 4.9$ and TDS $477 \mathrm{mg} / \mathrm{L}$ to pH 5.7 and TDS $316 \mathrm{mg} / \mathrm{L}$ (30 g banana peel ), pH 6.3 and TDS $310 \mathrm{mg} / \mathrm{L} \mathrm{(50} \mathrm{g}$ banana peel), pH 6.6 and TDS $333 \mathrm{mg} / \mathrm{L}$ (70 g banana peel), pH 6.9 and TDS 348 $\mathrm{mg} / \mathrm{L}(90 \mathrm{~g}$ banana peel). Then, for variations of filtration time, the results obtained were pH 5.3 and TDS 409 mg/L (3 hours), pH 5.5 and TDS 342 mg/L (5 
hours), pH 6.3 and TDS 314 mg/L (7 hours ), pH 6.6 and TDS 303 mg/L ( 9 hours ). Based on the results, it can be concluded that the kepok banana peel has high effectiveness and has the potential as an environmentally friendly biosorbent, and it can be further developed with an activation process and other parameter tests to reduce the impact of environmental pollution.

Keywords: banana peel, filtration, water quality

\section{PENDAHULUAN}

Indonesia kita ketahui sebagai negara dengan jumlah penduduk yang cukup besar mencapai 269,6 juta jiwa. Adanya peningkatan jumlah penduduk akan berdampak terhadap kebutuhan jumlah air bersih. Kemudian berdasarkan hasil pendataan Potensi Desa bagian kebencanaan yang dilakukan oleh Badan Pusat Statistik (BPS) Provinsi Riau, bahwa pencemaran lingkungan di Provinsi Riau pada tahun 2018 mengalami peningkatan jika dibandingkan dengan survei pada tahun 2014 . Adapun pencemaran yang terdata meliputi pencemaran air, udara dan tanah yang berasal dari limbah rumah tangga juga industri (Badan Pusat Statistik Provinsi Riau, 2018).

Beberapa upaya telah banyak dilakukan oleh pemerintah untuk dapat menanggulangi permasalahan pencemaran tersebut, namun sampai saat ini belum mencapai keadaaan optimal yang diinginkan dikarenakan sulitnya pengendalian pencemaran tersebut. Dari permasalahan tersebut, maka peneliti mencoba untuk melakukan perbaikan kualitas fisik air dengan menggunakan limbah kulit pisang sebagai media filtrasi. Selama ini beberapa penelitian telah menggunakan kulit pisang sebagai adsorben untuk mengurangi pencemaran air diantaranya (Suprabawati \& Dwiko, 2016), (Legiso dan Heni, 2019) dengan cara mencampurkan serbuk kulit pisang ke sampel air yang tercemar dan dilakukan proses pengadukan serta penyaringan. Perbedaan nya pada penelitian kali ini dengan tujuan untuk menghemat waktu, maka tidak dilakukan proses pengadukan dan penyaringan, melainkan serbuk kulit pisang dirakit kedalam kantong filtrasi sehingga proses filtrasi berjalan lebih cepat dan efektif .

Pemilihan kulit pisang sebagai media filtrasi dikarenakan Negara Indonesia termasuk kedalam 10 besar pada urutan ke enam sebagai produsen buah pisang terbesar di dunia dengan jumlah produksi sebesar 5.814.580 ton per tahun 2010 (Padam, B. S., Tin, H. S., Chye, F. Y.,; Abdullah, 2014) kemudian tahun 2013 meningkat menjadi 6.279.290 ton (Ambarita \& Bayu, 2015) namun selama ini limbah kulit pisang belum banyak dimanfaatkan terutama di daerah Riau sehingga hanya menjadi limbah dan sumber pencemaran lingkungan yang cukup besar dikarenakan saat ini sangat banyak usaha yang sedang berkembang menggunakan pisang sebagai bahan baku namun limbahnya masih dianggap tidak memiliki nilai ekonomis. Proses daur ulang terhadap suatu limbah dapat menawarkan sebuah potensi sampingan yang bermanfaat dibandingkan jika hanya dibuang langsung dan akan menyebabkan pencemaran pada lingkungan (Anal \& Jaisanti, 2014).

Berdasarkan hasil penelitian sebelumnya terkait kandungan kulit pisang diketahui bahwa kulit pisang Kepok memiliki kandungan vitamin C, vitamin B, kalsium, protein, selulosa, hemiselulosa, pigmen klorofil, lemak, arabinosa, galaktosa, rhamnosa, dan asam galacturonic yang dapat mengikat logam di air .Limbah kulit pisang juga dapat dipertimbangkan untuk penurunan kadar kekeruhan dan ion logam berat pada air yang terkontaminasi (Budiman;Hamidah;Hasria, 2018). Struktur dari bahan yang 
mengandung selulose dan lignin secara alami akan memberikan struktur berpori dan berpotensi untuk dimanfaatkan sebagai media filtrasi yang dapat mengadsorpsi tanpa diarangkan (Widjanarko;, 2006). Selulosa merupakan salah satu kandungan yang terdapat di dalam kulit pisang kepok dan kita ketahui bahwa selulosa merupakan polimer sederhana, membentuk ikatan kimia yang memiliki permukaan rantai selulosa seragam dan membentuk lapisan berpori. Material padatan berpori inilah yang menyerap bahanbahan berbahaya bagi lingkungan (Nasir La Hasan; Zakir, M; Budi, 2015). Selain itu kulit pisang juga terdiri dari atom nitrogen, sulfur dan bahan-bahan organik seperti asam carboxylic. Zat tersebut dapat berfungsi mengikat molekul pencemar dalam (Budiman,Hamidah,Hasria, 2018). Oleh karena itu penelitian ini dilakukan dengan tujuan kulit pisang dapat dijadikan sebagai media filtrasi untuk memperbaiki kualitas fisika air diantaranya tingkat kejernihan air, nilai pH dan TDS.

\section{METODE PENELITIAN}

1. Alat dan Bahan

a. Alat

Alat yang digunakan diantaranya peralatan gelas di laboratorium (labu ukur, gelas piala, gelas ukur, pipet volume, pipet tetes (Pyrex-Jpn)), neraca analitik (Kern: ABS 220-4), spatula (Usbeck-Germ), pisau, blender (Cosmos), pH meter (ATC) ,TDS meter (TDS-3 HM), pompa air (Amara P-1000), bak penampung, selang .

b. Bahan

Bahan yang digunakan adalah sampel air limbah artifisial, aquadest, limbah kulit pisang kepok.

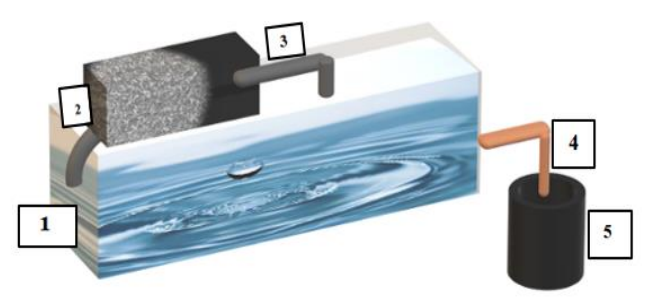

Keterangan Alat

1. Sumber Air Baku

2. Kotak Filter

3. Pipa Filtrasi

4. Pipa ke Bak Penampungan

5. Bak Penampungan Filtrasi

\section{Gambar 1. Skema Peralatan Filtrasi (Dok.Pribadi)}

\section{Prosedur Penelitian}

Prosedur penelitian yang dilakukan dengan langkah-langkah sebagai berikut :

\subsection{Preparasi Limbah Kulit Pisang}

Kulit pisang Kepok dikumpulkan dari limbah penjual goreng pisang di Daerah Marpoyan-Pekanbaru Riau. Kemudian kulit pisang tersebut dicuci dengan air mengalir untuk menghilangkan kotoran yang terbawa. Setelah itu dikeringkan di bawah sinar matahari selama 2-3 hari . Setelah kering kulit pisang dihaluskan 
dengan blender hingga terbentuk serbuk simplisia kulit pisang kepok (Musafira; \& Dzulkifli;, 2020).

\subsection{Pengaruh Jumlah Media Filtrasi dan Waktu Filtrasi Terhadap Tingkat} Kejernihan Air, pH dan TDS .

Dibuat variasi jumlah media filtrasi yaitu : $30 \mathrm{~g} ; 50 \mathrm{~g} ; 70 \mathrm{~g}$; dan $90 \mathrm{~g}$ kulit pisang kepok yang masing-masingnya dimasukan ke dalam kantong filter . Setelah itu dilakukan proses filtrasi dengan sirkulasi selama 5 jam sesuai dengan skema Gambar 1 untuk masing-masing variasi jumlah media filtrasi tersebut. Setelah itu dilakukan pengecekan perubahan kepekatan warna pengotor air limbah artifisial, perubahan nilai $\mathrm{pH}$ dan nilai TDS untuk ke 4 variasi tersebut. Setelah Variasi media filtrasi dilakukan pula variasi waktu filtrasi yaitu : 3 jam; 5 jam; 7 jam dan 9 jam dengan menggunakan $50 \mathrm{~g}$ kulit pisang kepok . Kemudian dilihat perubahan tingkat kejernihan air limbah artifisial, nilai $\mathrm{pH}$ dan TDS .

\section{HASIL PENELITIAN DAN PEMBAHASAN}

\section{Preparasi Sampel Kulit Pisang kepok}

Sampel kulit pisang yang telah didapatkan dibersihkan terlebih dahulu dengan air mengalir untuk menghilangkan pengotor yang terbawa saat proses pengumpulan sampel. Setelah itu kulit pisang dikeringkan selama 2-3 hari untuk menghilangkan kadar air yang terkandung di dalamnya. Kemudian setelah kering kulit pisang dihaluskan terlebih dahulu dengan blender agar dapat memperluas permukaan bidang sentuh sehingga proses filtrasi dapat lebih maksimal karena lebih banyak yang dapat mengikat pengotor pada limbah artifisial yang digunakan. Hal ini senada dengan yang diungkapkan (Arifiyana \& Devianti, 2020) bahwa penghalusan sampel untuk memperbesar luas permukaan biosorben. Peluang kontak proses filtrasi ataupun adsorbs akan semakin besar pula (Imani \& Sukwika, 2021). Rangkaian preparasi sampel dapat dilihat pada Gambar 2 dibawah ini :

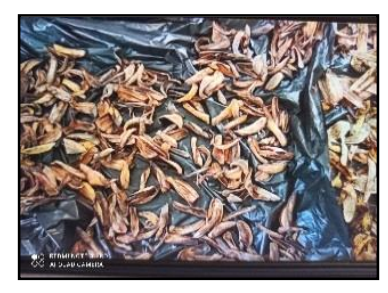

(a)

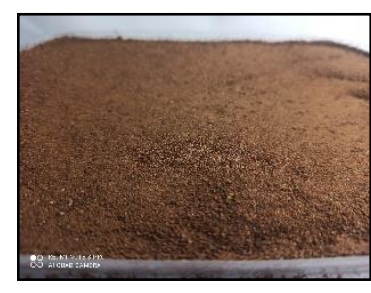

(b)

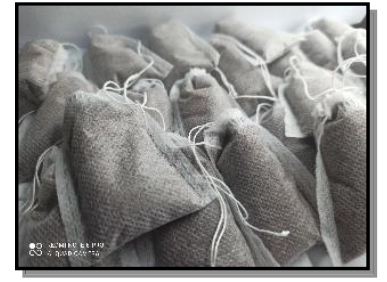

(c)

Gambar 2 : a. Pengeringan Kulit pisang ; b. Penghalusan sampel kulit pisang ; c. Kantong Filter yang telah diisi kulit pisang

Serbuk simplisia kulit pisang yang telah dimasukan ke kantong filter kemudian digunakan langsung sebagai media filtrasi untuk meningkatkan kualitas fisik air. Pada penelitian ini digunakan langsung kulit pisang tanpa dijadikan karbon aktif 
ataupun diaktivasi secara kimia dan fisika. Dengan tujuan melihat efektivitas kulit pisang tanpa campuran apapun karena didalamnya telah terkandung berbagai senyawa metabolit sekunder yang mempunyai kemampuan mengikat kotoran bahkan logam berat. Sesuai dengan yang diungkapkan pada penelitian sebelumnya bahwa limbah kulit pisang dapat dipertimbangkan untuk proses penurunan kadar kekeruhan dan ion logam berat pada air yang terkontaminasi. Kemudian (Widjanarko;, 2006) juga mengungkapkan bahwa struktur dari bahan yang mengandung selulose dan lignin secara alami akan memberikan struktur berpori dan berpotensi untuk dimanfaatkan sebagai media filtrasi yang dapat mengadsorpsi tanpa diarangkan . Hal ini sejalan dengan penelitian (Budiman;Hamidah;Hasria, 2018) yang mengungkapkan bahwa kandungan Kepok diantaranya vitamin $\mathrm{C}$, vitamin $\mathrm{B}$, kalsium, protein, selulosa, hemiselulosa, pigmen klorofil, lemak, arabinosa, galaktosa, rhamnosa, dan asam galacturonic.

2. Analisis Pengaruh Jumlah Media Filtrasi dan Waktu Filtrasi Limbah Kulit Pisang Kepok Terhadap Perubahan Kualitas Fisik Air (Tingkat Kejernihan, nilai pH dan TDS )

\section{a. Tingkat Kejernihan Air}

Proses peningkatan kualitas fisik air yang pertama diamati adalah perubahan tingkat kejernihan air. Kualitas air yang baik adalah jernih (bening) dan tidak keruh. Kekeruhan air disebabkan oleh partikel-partikel yang tersuspensi di dalam air yang menyebabkan air terlihat keruh, kotor, bahkan berlumpur (Legiso dan Heni, 2019).

Untuk proses penjernihan air dilakukan variasi jumlah media filtrasi yang menggunakan kulit pisang sebanyak $30 \mathrm{~g} ; 50 \mathrm{~g}$; $70 \mathrm{~g}$; dan $90 \mathrm{~g}$ yang masingmasing proses filtrasinya dilakukan selama 5 jam proses sirkulasi menggunakan pompa dengan kapasitas $600 \mathrm{~L} / \mathrm{H}$. Kemudian untuk variasi waktu filtrasi yaitu dilakukan selama 3 jam ; 5 jam ; 7 jam ; dan 9 jam. Adapun hasil yang didapatkan adalah terjadi peningkatan tingkat kejernihan air dari awalnya yang bewarna kecokelatan menjadi lebih bening. Proses Filtrasi dapat dilihat pada Gambar 3 dibawah ini :
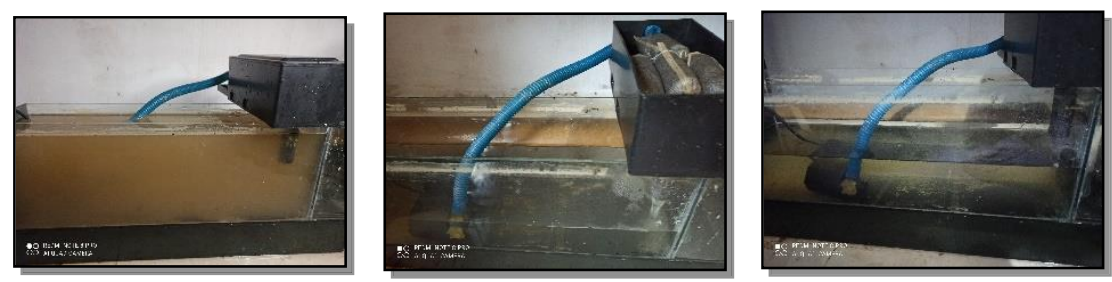

Gambar 3. Proses Filtrasi Air Limbah Artifisial dengan Kulit Pisang Kepok

Berdasarkan pengujian yang telah dilakukan dapat dilihat bahwa kulit pisang kepok dapat bertindak sebagai media filtrasi yang mempunyai kemampuan mengadsorbsi kotoran yang terdapat pada limbah artifisial sehingga terjadi peningkatan kualitas fisik air yang ditandai dengan perubahan air menjadi lebih 
jernih. Hal ini menandakan pengotor dari air tersebut telah terikat ke media filtrasi (kulit pisang kepok). Selulosa merupakan salah satu kandungan yang terdapat di dalam kulit pisang kepok dan kita ketahui bahwa selulosa merupakan polimer sederhana, membentuk ikatan kimia yang memiliki permukaan rantai selulosa seragam dan membentuk lapisan berpori. Material padatan berpori inilah yang menyerap bahan-bahan berbahaya bagi lingkungan (Nasir La Hasan; Zakir, M; Budi, 2015). Selain itu kulit pisang juga terdiri dari atom nitrogen, sulfur dan bahan-bahan organik seperti asam carboxylic. Zat tersebut dapat berfungsi mengikat molekul pencemar dalam air (Budiman;Hamidah;Hasria, 2018).

Dengan bertambahnya waktu filtrasi artinya sirkulasi yang terjadi semakin lama sehingga akan semakin banyak pengotor di dalam air yang dapat terikat pada kulit pisang kepok tersebut karena interaksi yang lebih lama. Hal ini sejalan dengan yang diungkapkan (Fatmawati \& Inayah, 2021) bahwa semakin lama waktu kontak maka semakin banyak kesempatan partikel saling bersinggungan dan terjadi adsorbsi atau penyerapan. Semakin lama waktu filtrasi yang dilakukan maka tingkat kejernihan air semakin tinggi yang dapat dilihat pada Gambar 4 dibawah ini :

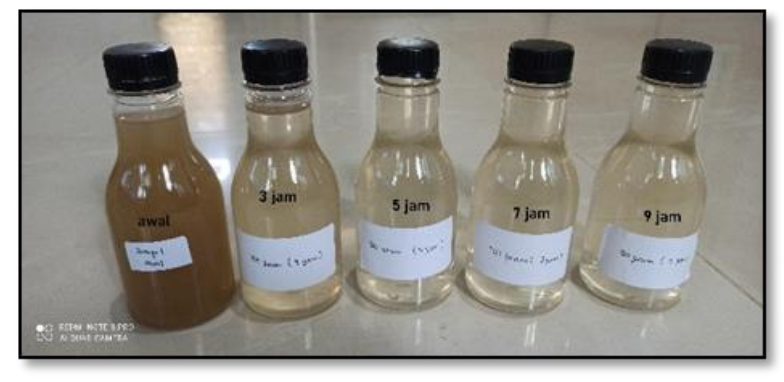

\section{Gambar 4. Peningkatan Kejernihan air dengan variasi waktu Filtrasi}

Begitu pula dengan variasi jumlah media filtrasi . Semakin banyak jumlah media filtrasi kulit pisang kepok yang digunakan ,maka terjadi peningkatan kejernihan air yang mengindikasikan bahwa semakin banyak partikel pengotor yang dapat berikatan dengan komponen di dalam kulit pisang. Hal ini sejalan dengan yang diungkapan (Anom, 2019) bahwa tingginya kemampuan adsorbsi suatu adsorben dipengaruhi oleh banyaknya dosis atau jumlah adsorben yang digunakan. Semakin banyak media filtrasi yang digunakan maka tingkat kejernihan air semakin tinggi yang dapat dilihat pada Gambar 5 dibawah ini : 


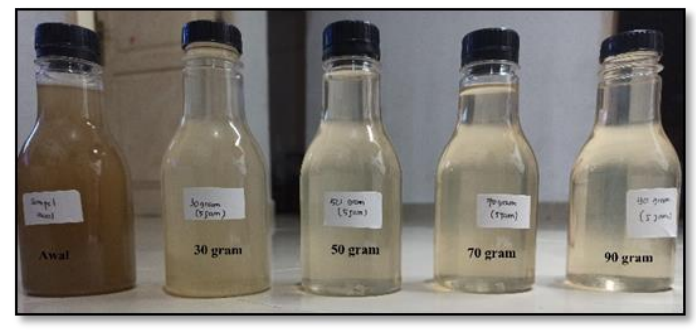

Gambar 5. Peningkatan Kejernihan air dengan variasi jumlah Media Filtrasi

Pada penelitian ini perubahan warna ataupun derajat kekeruhan nya tidak berdasarkan pengukuran hanya berdasarkan pengamatan langsung yang dapat dilihat pada Tabel 1 dibawah ini :

Tabel 1. Tingkat Kejernihan Air Dengan Variasi Waktu dan Jumlah Media Filtrasi

\begin{tabular}{cccccc}
\hline No & $\begin{array}{c}\text { Variasi } \\
\text { Waktu }\end{array}$ & $\begin{array}{c}\text { Tingkat } \\
\text { Kejernihan } \\
\text { Air }\end{array}$ & $\begin{array}{c}\text { Variasi } \\
\text { Jumlah Media } \\
\text { Filtrasi }\end{array}$ & $\begin{array}{c}\text { Tingkat } \\
\text { Kejernih } \\
\text { an Air }\end{array}$ & Keterangan \\
\hline 1 & Awal & + & Awal & + & $\begin{array}{c}\text { Bewarna kecokelatan } \\
\text { Bening dengan } \\
\text { sedikit pengotor } \\
2\end{array}$ \\
3 jam & ++ & 30 gram & ++ & Bening \\
3 & 5 jam & +++ & 50 gram & +++ & Bening \\
4 & 7 jam & ++++ & 70 gram & ++++ & Bening \\
5 & 9 jam & +++++ & 90 gram & +++++ & \\
\hline
\end{tabular}

Ket. Tanda + ( bertambahnya tanda + artinya tingkat kejernihan semakin tinggi)

\section{b. Perubahan Nilai pH Dengan Variasi Waktu dan Jumlah Media Filtrasi}

Nilai $\mathrm{pH}$ merupakan suatu indeks kadar ion hidrogen $\left(\mathrm{H}^{+}\right)$yang mencirikan keseimbangan asam dan basa. Nilai $\mathrm{pH}$ pada suatu perairan mempunyai pengaruh yang besar terhadap organisme perairan sehingga seringkali dijadikan petunjuk untuk menyatakan baik buruknya suatu perairan (Yulis, 2018). Berdasarkan hal tersebut maka pada penelitian ini juga dilakukan pengukuran perubahan nilai $\mathrm{pH}$ air dengan menggunakan media filtrasi kulit pisang. Hasil pengukuran terhadap nilai $\mathrm{pH}$ dapat dilihat pada Tabel 2 dibawah ini

Tabel 2. Perubahan Nilai pH Dengan Variasi Waktu dan Jumlah Media Filtrasi

\begin{tabular}{lcccc}
\hline No & $\begin{array}{c}\text { Variasi } \\
\text { Waktu }\end{array}$ & Nilai $\mathbf{p H}$ & $\begin{array}{c}\text { Variasi Jumlah } \\
\text { Media Filtrasi }\end{array}$ & Nilai pH \\
\hline 1 & Awal & 4,9 & Awal & 4,9 \\
2 & 3 jam & 5,3 & 30 gram & 5,7 \\
3 & 5 jam & 5,5 & 50 gram & 6,3 \\
4 & 7 jam & 6,3 & 70 gram & 6,6 \\
5 & 9 jam & 6,6 & 90 gram & 6,9 \\
\hline
\end{tabular}

Berdasarkan Tabel 2 dapat dilihat bahwa kulit pisang kepok sebagai media filtrasi dapat meningkatkan nilai $\mathrm{pH}$ secara cukup signifikan. Dimana kita ketahui bahwa $\mathrm{pH}$ air yang aman berkisar 6-9. Pada penelitian ini $\mathrm{pH}$ awal air limbah 
artifisial 4,9 yang kemudian setelah proses filtrasi dengan variasi waktu filtrasi terjadi peningkatan $\mathrm{pH}$ air menjadi 5,3 (filtrasi 3 jam); 5,5 (filtrasi 5 jam) ; 6,3 (filtrasi 7 jam) dan 6,6 (filtrasi 9 jam). Semakin lama waktu filtrasi maka nilai $\mathrm{pH}$ menjadi lebih tinggi seiring dengan berkurangnya pengotor-pengotor yang mempengaruhi nilai $\mathrm{pH}$. Kemudian dapat dilihat juga bahwa dengan variasi jumlah media filtrasi juga dapat menaikan nilai $\mathrm{pH}$ dari 4,9 menjadi 5,7 (kulit pisang $30 \mathrm{~g}$ ) ;6,3(kulit pisang $50 \mathrm{~g}$ ) ; 6,6 (kulit pisang $70 \mathrm{~g}$ ) dan 6,9 (kulit pisang $90 \mathrm{~g}$ ). Semakin banyak kulit pisang yang digunakan maka terjadi peningkatan nilai $\mathrm{pH}$ dari air limbah tersebut yang mengindikasikan bahwa semakin banyak pengotor yang terikat pada kulit pisang. Dapat dilihat bahwa dari $\mathrm{pH}$ yang terbilang asam berubah hampir mendekati $\mathrm{pH}$ netral dan masuk kategori aman. Komponen aktif didalam kulit pisang dapat mempengaruhi keberadaan ion $\mathrm{H}^{+}$di dalam air sehingga mempengaruhi nilai $\mathrm{pH}$. Hal ini sejalan dengan penelitian (Legiso; 2019) yang mengungkapkan bahwa karbon aktif dari kulit pisang kepok baik dalam meningkatkan nilai $\mathrm{pH}$. Begitu pula halnya dengan penelitian (Suharlina \& Umroh, 2016) yang menyatakan bahwa adanya kenaikan nilai $\mathrm{pH}$ pada partikel dengan perlakuan bubuk kulit pisang.

c. Perubahan Nilai TDS Dengan Variasi Waktu dan Jumlah Media Filtrasi

TDS adalah jumlah padatan terlarut dalam air, nilai TDS menunjukkan kandungan zat organik dan anorganik, mineral serta material yang terlarut di dalamnya (Ariani \& Nurhasanah, 2020) Kemudian (Hafni, 2012) menyatakan bahwa kekeruhan air dapat ditimbulkan oleh adanya bahan-bahan anorganik dan organik yang terkandung dalam air. Berdasarkan hal tersebut salah satu parameter penting yang perlu diamati terkait kualitas air adalah nilai TDS atau (Total Dissolved Solid). Pengaruh perlakuan kulit pisang terhadap nilai TDS air dapat dilihat pada Tabel 3 dibawah ini :

Tabel 3. Perubahan Nilai pH Dengan Variasi Waktu dan Jumlah Media Filtrasi

\begin{tabular}{ccccc}
\hline No & $\begin{array}{c}\text { Variasi } \\
\text { Waktu }\end{array}$ & Nilai TDS (mg/L) & $\begin{array}{c}\text { Variasi Jumlah } \\
\text { Media Filtrasi }\end{array}$ & $\begin{array}{c}\text { Nilai TDS } \\
\text { (mg/L) }\end{array}$ \\
\hline 1 & Awal & 477 & Awal & 477 \\
2 & 3 jam & 409 & 30 gram & 316 \\
3 & 5 jam & 342 & 50 gram & 310 \\
4 & 7 jam & 314 & 70 gram & 333 \\
5 & 9 jam & 303 & 90 gram & 348 \\
\hline
\end{tabular}

Berdasarkan Tabel 3 dapat dilihat bahwa media filtrasi kulit pisang kepok berpengaruh terhadap nilai TDS air limbah artifisal. Untuk variasi waktu filtrasi nilai awal TDS sebesar $477 \mathrm{mg} / \mathrm{L}$ menjadi $409 \mathrm{mg} / \mathrm{L}$ (filtrasi 3 jam), $342 \mathrm{mg} / \mathrm{L}$ (filtrasi 5 jam), $314 \mathrm{mg} / \mathrm{L}$ (filtrasi 7 jam) dan 303 (filtrasi 9 jam ). Terjadi penurunan seiring dengan bertambahnya waktu filtrasi. Hal ini menunjukan kulit pisang mempunyai kemampuan mengikat zat padat terlarut pada air limbah tersebut sehingga terjadi penurunan. Semakin lama sirkulasi yang terjadi maka intensitas interaksi semakin besar. Hal ini sejalan dengan yang diungkapkan (Hanifah \& Hadisoebroto, 2020) bahwa secara umum kandungan kulit pisang terdiri dari mineral, vitamin , protein, karbohidrat dan lemak. Salah satu zat aktif yang mempunyai peran dalam proses koagulasi adalah protein. Hal inilah yang 
menyebabkan air limbah berubah menjadi lebih jernih dan TDS berkurang. Untuk variasi media filtrasi juga terdapat perubahan nilai TDS yaitu dari $477 \mathrm{mg} / \mathrm{L}$ di awal menjadi $316 \mathrm{mg} / \mathrm{L}$ ( $30 \mathrm{~g}$ kulit pisang), $310 \mathrm{mg} / \mathrm{L}$ (50 g kulit pisang), 333 $\mathrm{mg} / \mathrm{L}$ (70 g kulit pisang) dan $348 \mathrm{mg} / \mathrm{L} \mathrm{(90} \mathrm{g} \mathrm{kulit} \mathrm{pisang).} \mathrm{Pada} \mathrm{variasi} \mathrm{media}$ filtrasi di awal terjadi penurunan TDS karena pengikatan pencemar atau zat teralrut di dalam air oleh komponen dari kulit pisang, namun pada saat jumlah kulit pisang bertambah banyak yakni pada saat jumlahnya $70 \mathrm{~g}$ terjadi peningkatan TDS kembali. Hal ini disebabkan terdapat kulit pisang yang ikut terlarut didalam air sehingga secara tidak langsung akan menambah komponen organik dan anorganik air limbah tersebut. Hal ini sejalan dengan penelitian (Wicakso \& Mirwan, 2012) bahwa terjadi peningkatan nilai TDS pada saat pengaplikasian karbon aktif kulit pisang raja karena adanya kulit pisang raja yang ikut terlarut di dalam air .

\section{SIMPULAN}

Berdasarkan penelitian yang telah dilakukan dapat disimpulkan bahwa serbuk kulit pisang kepok tanpa dijadikan arang aktif ataupun diaktivasi secara kimia dan fisika tetap mempunyai efektivitas dalam memperbaiki kualitas air diantaranya mempengaruhi tingkat kejernihan air. Kemudian aplikasi kulit pisang kepok terhadap air limbah artifisial juga dapat meningkatkan nilai $\mathrm{pH}$ secara signifikan dari asam menjadi netral yakni rentang 4,9- 6,9. Serbuk simplisia kulit pisang juga dapat mempengaruhi nilai TDS pada badan air meskipun persentase penurunan nilai TDS tidak cukup signifikan dikarenakan kulit pisang sendiri mengandung berbagai macam zat mineral yang kemungkinan dapat larut didalam air dan menambah konsentrasi TDS air tersebut. Untuk penelitian selanjutnya dapat diteliti lagi pengaruh kulit pisang terhadap standar baku mutu air yang lain dan

\section{UCAPAN TERIMA KASIH}

Terima kasih kami ucapkan kepada LPPM Universitas Islam Riau (UIR) yang telah mendanai penelitian ini dengan Kontrak Penelitian Nomor: 238/KONTRAK/LPPM-UIR/5-2020 sehingga penelitian ini dapat terlaksana dengan baik serta pihak-pihak yang dilibatkan dalam penelitian ini.

\section{DAFTAR RUJUKAN}

Ambarita, M. D. Y. dan, \& Bayu, E. S. (2015). Identifikasi Karakter Morfologis Pisang (Musa Spp.) Di Kabupaten Deli Serdang. Jurnal Agroekoteknologi Universitas Sumatera Utara, 4(1), 1911-1924.

Anal, A. K. dan, \& Jaisanti, S. (2014). Enhanced yield of phenolic extracts from banana peels (Musa acuminata Colla AAA) and cinnamon barks (Cinnamomum varum) and their antioxidative potentials in fish oil. Journal of Food Science and Technology, 51(10), 2632-2639.

Anom;, H. (2019). Bioadsorben Kulit Pisang Kepok (Musa Acuminate L.) Dalam Menurunkan Kadar Timbal $(\mathrm{Pb})$ Pada Larutan $\mathrm{Pb}$. Jurnal Penelitian Kesehatan Suara Forikes, 10(4), 1-7.

Ariani, D. dan, \& Nurhasanah. (2020). Analisis Kandungan TDS dan Mineral pada Air Hujan untuk Konsumsi dengan Penambahan Karbon Aktif Kulit Pisang Kepok (Musa acuminate L.). Prisma Fisika, 8(1), 10. 
Arifiyana, D., \& Devianti, V. A. (2020). BIOSORPSI LOGAM BESI (Fe) DALAM MEDIA LIMBAH CAIR ARTIFISIAL MENGGUNAKAN ADSORBEN KULIT PISANG KEPOK (Musa acuminate). Jurnal Kimia Riset, 5(1), 1-8.

Badan Pusat Statistik Provinsi Riau. (2018). Statistik Air Bersih Provinsi Riau. CV.MN.Grafika.

Budiman;Hamidah;Hasria. (2018). LIMBAH KULIT PISANG KEPOK (Musa acuminate) SEBAGAI BIOFILTER ZAT BESI (Fe) DAN ZAT KAPUR (CaCO3). PROMOTIF: Jurnal Kesehatan Masyarakat, 8(2), 152-158.

Fatmawati, S. dan, \& Inayah, S. N. (2021). Arang Aktif Gambut sebagai Filter Logam Berat Mercury (Hg). Jurnal Ilmiah Sains, 21(1), 63.

Hafni. (2012). Proses Pengolahan Air Bersih pada PDAM Padang. Jurnal Momentum, 13(2), 12-26.

Hanifah, H. N. dan, \& Hadisoebroto. (2020). Efektivitas Biokoagulan Cangkang Telur Ayam Ras dan Kulit Pisang Kepok (Musa Balbisiana ABB) dalam Menurunkan Turbiditas, TDS, dan TSS dari Limbah Cair Industri Farmasi. Al-Kimiya, 7(1), 4754.

Imani, A. dan, \& Sukwika, T. (2021). Karbon Aktif Ampas Tebu sebagai Adsorben Penurun Kadar Besi dan Mangan Limbah Air Asam Tambang. Jurnal Teknologi, 13(1), 33-42.

Legiso dan Heni, J. (2019). Perbandingan Efektivitas Karbon Aktif Sekam Padi Dan Kulit Pisang Kepok Sebagai Adsorben Pada Pengolahan Air Sungai Enim. Seminar Nasional Sains Dan Teknologi 2019, 1-13.

Musafira;, \& Dzulkifli; (2020). Penyerapan Ion Logam Merkuri Menggunakan Arang Aktif Limbah Kulit Pisang Kepok (Musa paradisiaca Formatypica). KOVALEN: Jurnal Riset Kimia, 6(1), 39-44.

Nasir La Hasan; Zakir, M; Budi, P. (2015). Desilikasi karbon aktif sekam padi sebagai adsorben hg pada limbah pengolahan emas di kabupaten buru propinsi maluku. Indonesia Chimica Acta, 7(2), 1-11.

Padam, B. S., Tin, H. S., Chye, F. Y., ; Abdullah, M. I. (2014). ). Banana by-products: an under-utilized renewable food biomass with great potential. . . Journal of Food Science and Technology, 51(12), 3527-3545.

Suharlina, E. dan, \& Umroh. (2016). Penggunaan Kulit Pisang Kepok (Musa Acuminate) pada Air Kolong yang Mengandung Tembaga (Cu). Sumberdaya Perairan, 10(1), 110-117.

Suprabawati, A., \& Dwiko, D. D. (2016). Serbuk Kulit Pisang Tanduk (Musa)"Horn" Ijuk Enau Dan Serbuk Sabut Kelapa Sebagai Bioadsorben Logam Berat Cd (Ii) Dan Penjernih Air. Kartika Jurnal Ilmiah Farmasi, 4(1), 37-41.

Wicakso, D. R. dan, \& Mirwan. (2012). Upaya Penurunan Kadar Merkuri Dalam Media Air Menggunakan Adsorben 2-Mercaptobenzothiazole (Mbt)-Lempung Aktif. Konversi, 1(1), 7-12.

Widjanarko;, W. (2006). Kinetika Adsorpsi Zat Warna Congo Red Dan Rhodamine B Dengan Menggunakan Serabut Kelapa Dan Ampas Tebu. Jurnal Teknik Kimia Indonesia., 5(3), 461-467.

Yulis, P. A. R. (2018). Analisis Kadar Logam Merkuri (Hg) Dan (Ph) Air Sungai Kuantan Terdampak Penambangan Emas Tanpa Izin (PETI). Orbital, 2(1), 28-36. 